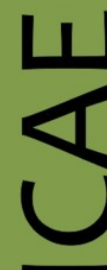

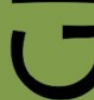

ex Instituto Archaeologico Universitatis de Rolando Eötvös nominatae

O

$\overrightarrow{0}$

山

$\leftarrow$

I

$\cup$

ه

$\leftarrow$

u

Ш

Z

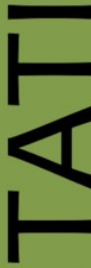

œ

ш

n

n

$\varnothing$
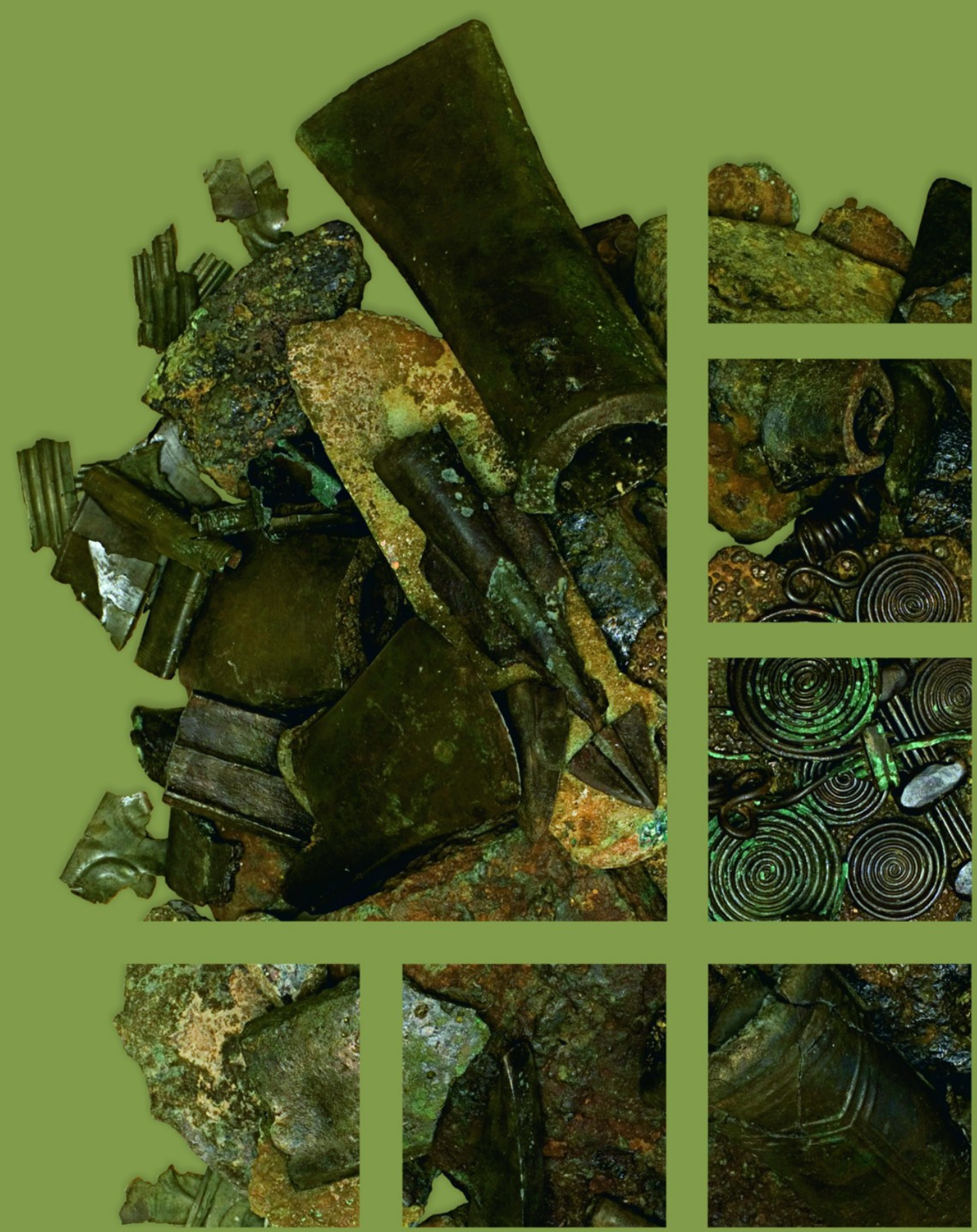


\section{Dissertationes Archaeologicae ex Instituto Archaeologico}

Universitatis de Rolando Eötvös nominatae Ser. 3. No. 2.

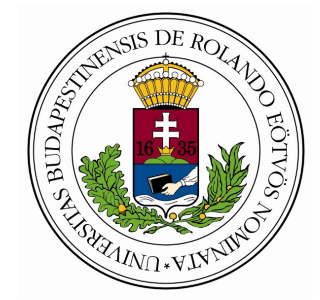

Budapest 2014 
Dissertationes Archaeologicae ex Instituto Archaeologico Universitatis de Rolando Eötvös nominatae

Ser. 3. No. 2.

Editor-in-chief:

DÁvid BARTus

Editorial board:

LÁsZló BARTOSIEWICZ

LÁSZLÓ BORHY

IsTVÁN FELD

GÁBOR KALLA

PÁL RACZKY

MiKLÓs SzABÓ

TIVADAR VIDA

Technical editors:

DÁvid BARTus

GÁBOR VÁCZI

ANDRÁs BÖDŐCS

DÁNIEL SZABÓ

Proofreading:

SZILVIA SzÖLLősI

Available online at http://dissarch.elte.hu Contact: dissarch@btk.elte.hu

$$
\begin{aligned}
& \text { PUBLIC } \\
& \text { KNOWLEDGE } \\
& \text { PROJECT }
\end{aligned}
$$

(c) Eötvös Loránd University, Institute of Archaeological Sciences

Budapest 2014 


\section{Contents}

\section{SElected PAPERS OF THE XI. Hungarian CONFERENCE on Classical Studies}

Ferenc BARNA

Venus mit Waffen. Die Darstellungen und die Rolle der Göttin in der Münzpropaganda

der Zeit der Soldatenkaiser (235-284 n. Chr.)

Dénes GABLER

A belsó vámok szerepe a rajnai és a dunai provinciák importált kerámiaspektrumában

Lajos MATHÉDESZ

Római bélyeges téglák a komáromi Duna Menti Múzeum gyújteményében

Katalin OtTOMÁNYI

Újabb római vicusok Aquincum territoriumán

Eszter SÜVEGH

Hellenistic grotesque terracotta figurines. Problems of iconographical interpretation

András SzABó

Some notes on the rings with sacred inscriptions from Pannonia

István VIDA

The coinage of Flavia Maxima Helena

\section{Articles}

Gábor TARBAY

Late Bronze Age depot from the foothills of the Pilis Mountains

Csilla SÁRó

Roman brooches from Paks-Gyapa - Rosti-puszta

András BöDőcs - Gábor KovÁcs - Krisztián ANDERKó

The impact of the roman agriculture on the territory of Savaria

Lajos JuHÁsz

Two new Roman bronzes with Suebian nodus from Brigetio

\section{FIELD REPORTS}

Zsolt MESTER - Norbert FARAGó - Attila KirÁLy

The first in situ Old Stone Age assemblage from the Rába Valley, Northwestern Hungary

Pál RACZky - Alexandra ANDERs - Norbert FARAgó - Gábor MÁRKus

Short report on the 2014 excavations at Polgár-Csőszhalom 
Preliminary Report on the first season of fieldwork in Berettyóúffalu-Szilhalom

Márton SzILÁgyi - András FüZESI - Attila VIRÁG - Mihály GASPARIK

A Palaeolithic mammoth bone deposit and a Late Copper Age Baden settlement and enclosure

Preliminary report on the rescue excavation at Szurdokpüspöki - Hosszú-dúlö II-III. (M21 site No. 6-7)

Kristóf FüLÖP - Gábor VÁcZI

Preliminary report on the excavation of a new Late Bronze Age cemetery

from fobbágyi (North Hungary)

Lőrinc TimÁr - Zoltán CzAJLik - András BöDőcs - Sándor PuszTA

Geophysical prospection on the Pâture du Couvent (Bibracte, France). The campaign of 2014

Dávid BARtus - László Borhy - Gabriella Delbó - Emese SzÁmadó

Short report on the excavations in the civil town of Brigetio (Szőny-Vásártér) in 2014

Dávid BARTus - László BorHy - Emese SzÁMADó

A new Roman bath in the canabae of Brigetio

Short report on the excavations at the site Szőny-Dunapart in 2014

Dávid BARTus - László Borhy - Zoltán CzAjlik - Balázs Holl -

Sándor PuszTA - László RuPNiK

Topographical research in the canabae of Brigetio in 2014

Zoltán CZAJLIK - Sándor BERECKI - László RUPNIK

Aerial Geoarchaeological Survey in the Valleys of the Mureș and Arieș Rivers (2009-2013)

Maxim MoRDovin

Short report on the excavations in 2014 of the Department of Hungarian Medieval

and Early Modern Archaeology (Eötvös Loránd University, Budapest)

Excavations at Castles Čabrad' and Drégely, and at the Pauline Friary at Sáska

\section{Thesis Abstracts}

Piroska Csengeri

Late groups of the Alföld Linear Pottery culture in north-eastern Hungary

New results of the research in Borsod-Abaúj-Zemplén County

Ádám Bíró

Weapons in the 10-11th century Carpathian Basin

Studies in weapon technology and methodology - rigid bow applications and southern import

swords in the archaeological material

Márta DARÓcZI-SzABó

Animal remains from the mid 12th-13th century (Árpád Period) village of Kána, Hungary

Károly BELÉNYESY

A 15th-16th century cannon foundry workshop in Buda

Craftsmen and technology of cannon moulding and the transformation of military technology

from the Renaissance to the Post Medieval Period 
István RINGER

Manorial and urban manufactories in the 17th century in Sárospatak

\section{BIBLIOGRAPHY}

László BORHY

565

Bibliography of the excavations in Brigetio (1992-2014) 


\title{
Two new Roman bronzes with Suebian nodus from Brigetio
}

\author{
LAJOS JuHÁsz \\ MTA-ELTE Research Group for \\ Interdisciplinary Archaeology \\ jlajos3@gmail.com
}

\begin{abstract}
The depiction of foreign men with their hair tied in a knot is a well known subject in Roman art. This was the distinctive hairstyle of some Germanic tribes. According to Tacitus this nodus was typically worn by free Suebian men by combing their long hair to the front and tying it together. ${ }^{1}$ These representations are most usually found in the provinces along the border of the Germanic tribes, but some are also known from Rome itself and even from barbarian territories. Two bronze pieces depicting a male head and a bust with the Suebian nodus were recently uncovered during the summer excavations of the Department of Classical and Roman Archaeology of the Eötvös Loránd University (Budapest) in the ancient Roman town of Brigetio (Komárom/Szőny-Vásártér).
\end{abstract}

\section{Introduction}

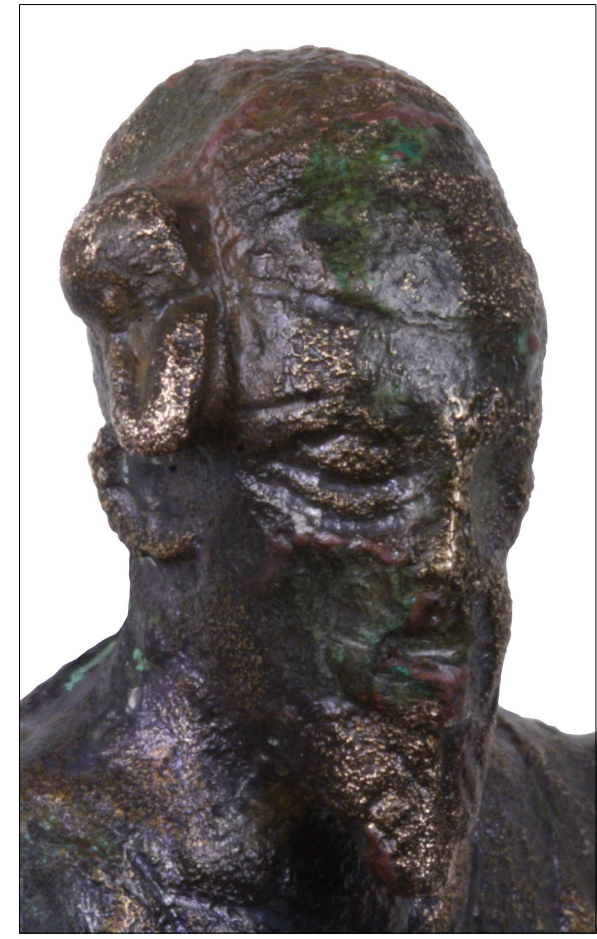

Fig. 1. Bronze bust of a Suebian man with nodus found in 2009 at Brigetio. (Photo: D. Bartus)
The first, a 4,75 cm tall and 4,1 cm wide bronze bust of a man was found in 2009 in a cellar amongst other debris with which the cellar was filled up (Fig. 1). ${ }^{2}$ The chest is decorated with five vertical and two diagonal incisions that indicate clothing. The bust is surrounded at the bottom and its sides by six triangular shaped leaves, with incised venations. The geometric shape of the floral ornament is a completely decomposed acanthus leaf (Fig. 2). On the right temple of the long and narrow bearded head the Suebian nodus can be seen. The incised decoration of the triangular beard is similar to the venation of the leaves. The almond-shaped eyes are proportionally too large for the head. The back side of the bust is flat with a $0,4 \times 0,4 \mathrm{~cm}$ square shaped hole, which held a pin that was used to fasten it to some kind of wooden object. The leaves do not follow the flat backside, but protrude sharply towards the front. The whole surface of the bust shows traces of heavy abrasions. The best preserved part is the right side of the head, where the nodus is found. The other side of the face suffered the most damage, where only the ear protrudes somewhat from the even surface. The leaves around the bust are also significantly worn.

1 Later the nodus was also applied by other Germanic tribes. (Tacitus, Germania 38). For a more detailed discussion about the nodus see KRIERER 2004, 100-111.

2 BorHy - SzÁMAdó 2010, 250-251; BARTus 2011, 21, Fig. 3. 


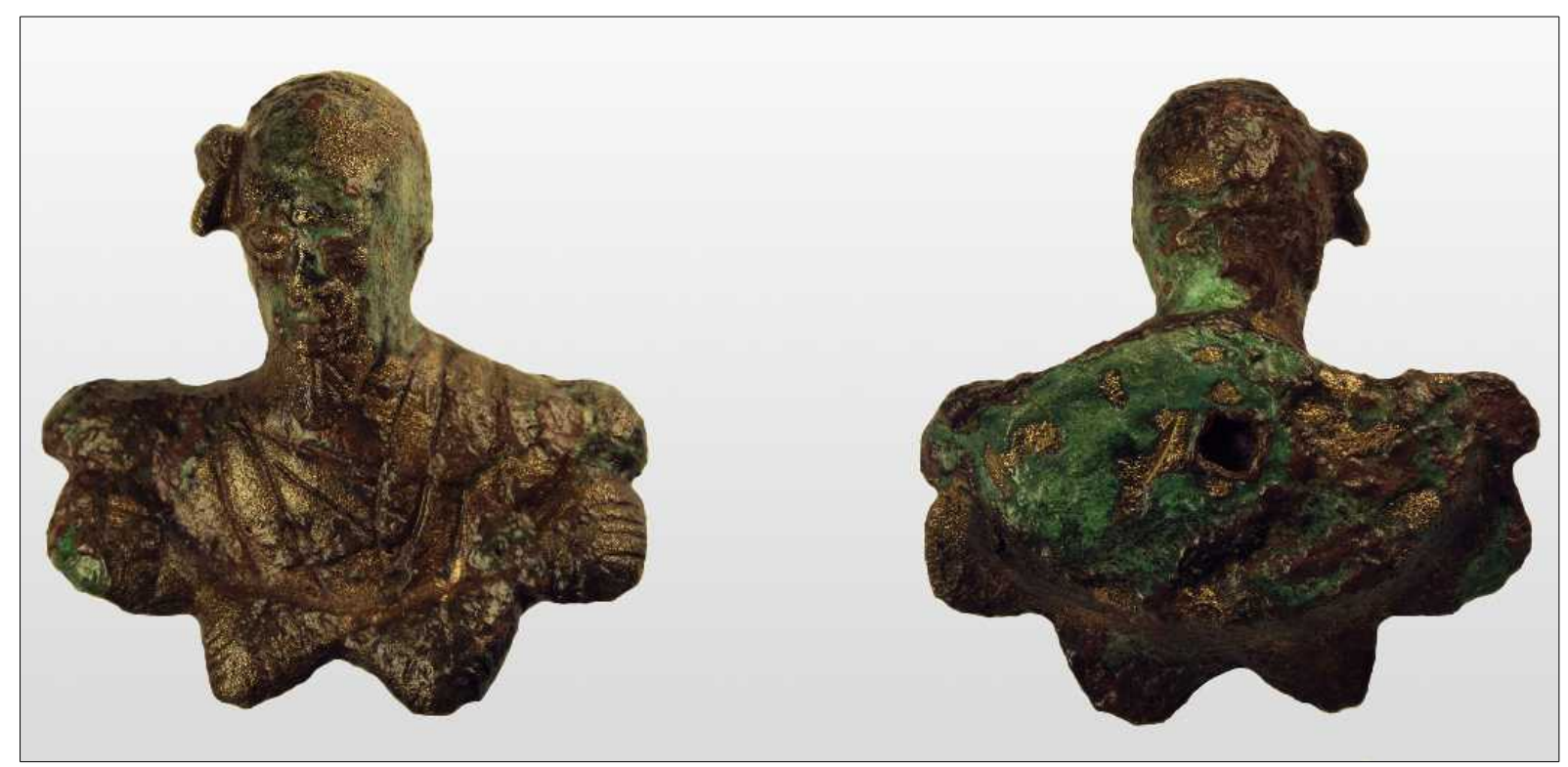

Fig. 2. Bronze bust of a Suebian man with nodus found in 2009 at Brigetio.

(Photo: D. Bartus)

The second bronze with a nodus was found in 2014 some 30 meters east of the previous one. ${ }^{3}$ This is only a 3,6 cm tall and $1,8 \mathrm{~cm}$ wide head that measures $2,7 \mathrm{~cm}$ in depth (Fig. 3). On the bottom it terminates in a small iron pin that is $1 \mathrm{~cm}$ in depth and $0,7 \mathrm{~cm}$ in height. The pin shows fracture marks at the back with traces of another $0,4 \times 0,4 \mathrm{~cm}$ sized pin, just like on the previous object. This means that the head was applied onto a surface so that the back of the head (which is also quite flat) and not the bottom end of the pin faced the decorated object. The head is again of an elongated form with the characteristic Suebian knot at the right temple. The right side is flatter due to abrasions. Interestingly enough the beard curves forward in a semicircular manner, which is unique amongst the representations of men with nodus. The hair and beard is decorated with incisions.

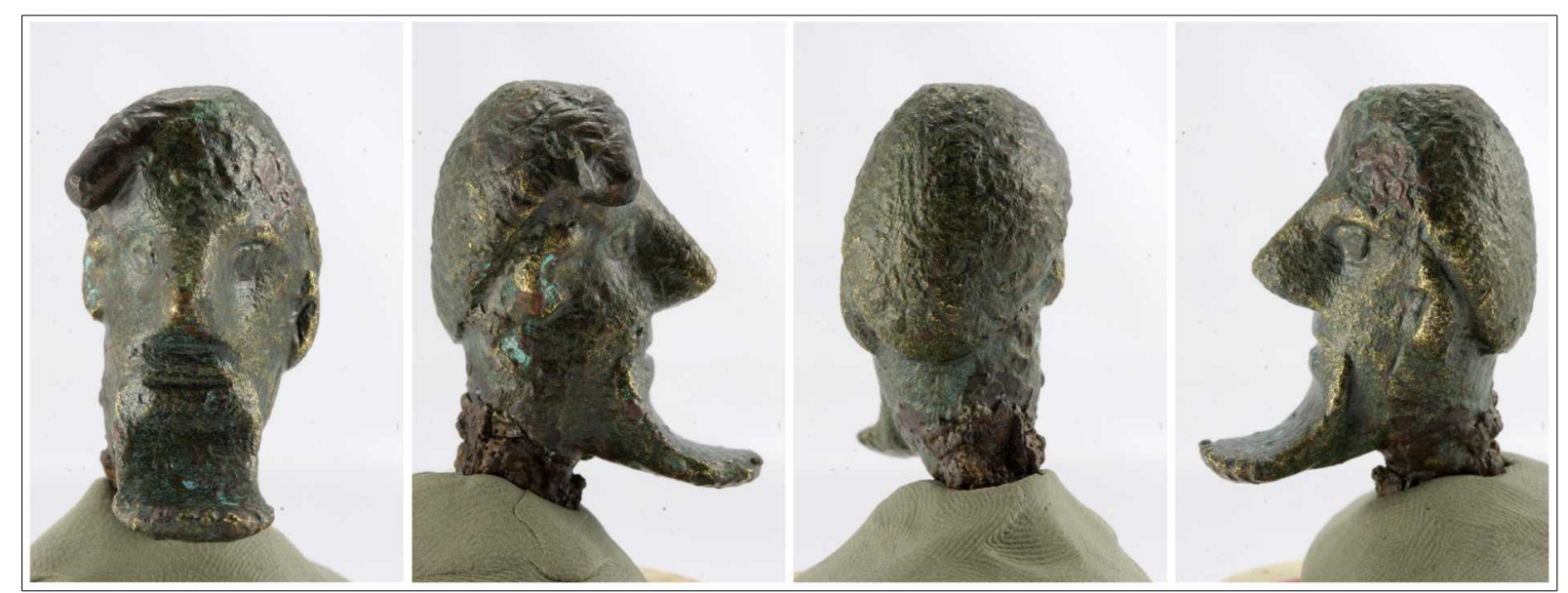

Fig. 3. Bronze head of a Suebian man with nodus found in 2014 at Brigetio. (Photo: D. Bartus). 


\section{Parallels}

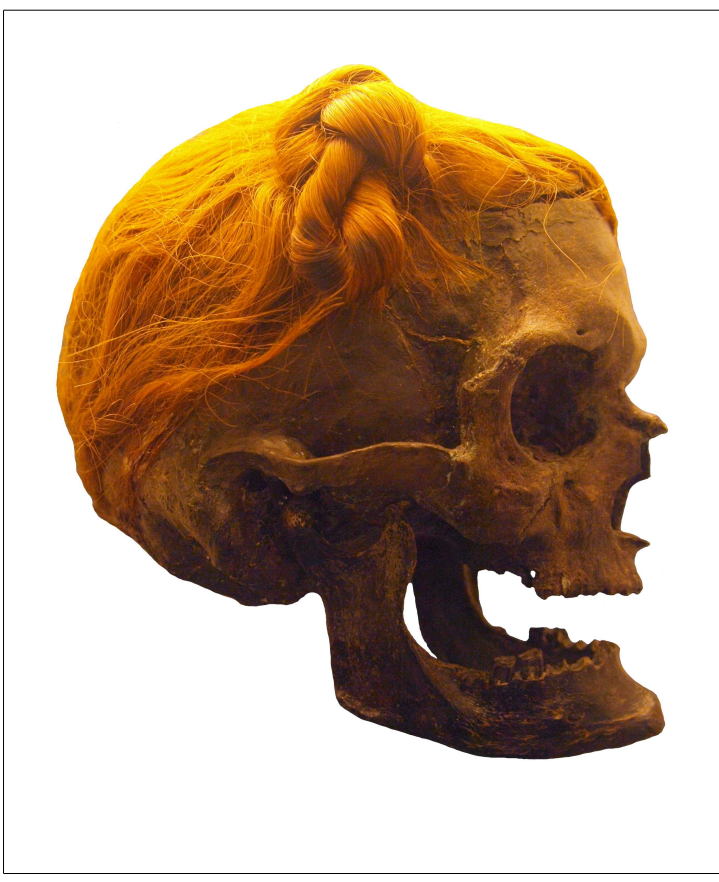

Fig. 4. The Osterby head with Suebian nodus (http://en.wikipedia.org/wiki/Suebian knot\#mediaviewer/File:Osterby_Man_Suebian-Knot.jpg)

The Suebian nodus can be seen on various Roman artefacts for example the Column of Trajan or the Column of Marcus Aurelius. ${ }^{4}$ Due to some extraordinarily lucky circumstances there are also original pieces that were preserved on bog bodies in Osterby (Fig. 4) and Dätgen in northern Germany. ${ }^{5}$ But the best parallel to the two new finds from Brigetio is found amongst a series of depictions with nodus found mostly in bronze, but some also in terracotta. ${ }^{6}$ These can be grouped into 6 different categories: busts, heads, as well as standing, seated, kneeling and recumbent figures.

\section{Busts}

There are 12 busts with nodus in bronze and terracotta, which makes this the largest group. The bust from Brigetio, in spite of the heavy abrasions and the inferior quality, belongs to the more decorative group of the bronze Suebian depictions. ${ }^{7}$ Apart from the one found in 2009, another one is known from Brigetio, which is often cited because of its high quality (Fig. 5). ${ }^{8}$ The depiction is more realistic, the craftsmanship more detailed than on the recently discovered one. The nodus itself is of different shape; it is longer and more detailed. The beard on the elongated face terminates in a pointy end. The ribs are indicated by horizontal lines which are tending upwards. The bust is surrounded by five leaves which end before the shoulder. The leaves stand upwards and show no signs of venation, unlike on the newly discovered piece. On the bottom of the central and biggest leave a fracture can be seen, where presumably once the protrusion for the fastening was situated. ${ }^{9}$ The pin protruding from the hollow back side served as further fastening, which is a very different solution compared to the newly discovered piece. There is a considerable difference in size between the two busts from Brigetio. The one in the Hungarian National Museum is 9,8 cm tall, while the other one is almost half the size. Thus, it can be concluded that the two pieces served two different purposes.

4 Krierer 2004, 129-142.

5 KRIERER 2004, 112-113.

6 The representations in stone are not dealt with in this paper, since they are of considerably different nature.

7 For the differences between the comical, scornful and artistic Germanic depictions see JÁRDÁNYI-PAULOVICS 1945, 244245; PetÉnYi 1993, 58, 61; Krierer 2004, 119.

8 Hungarian National Museum, Inv. no. 4-1933.4. Nothing is known about the find circumstances. I. Járdányi-Paulovics sees in the bust a Quadian king, against whom Marcus Aurelius led the campaign. (JÁrdÁNYI-PAUlOvics 1945, 251).

9 JÁrdÁnyi-PAulovics 1945, 250. For similar fastening see Fleischer 1967, Nr. 71 (Hermes bust with calyx leaves); Krierer 2004, Kat. 298. 


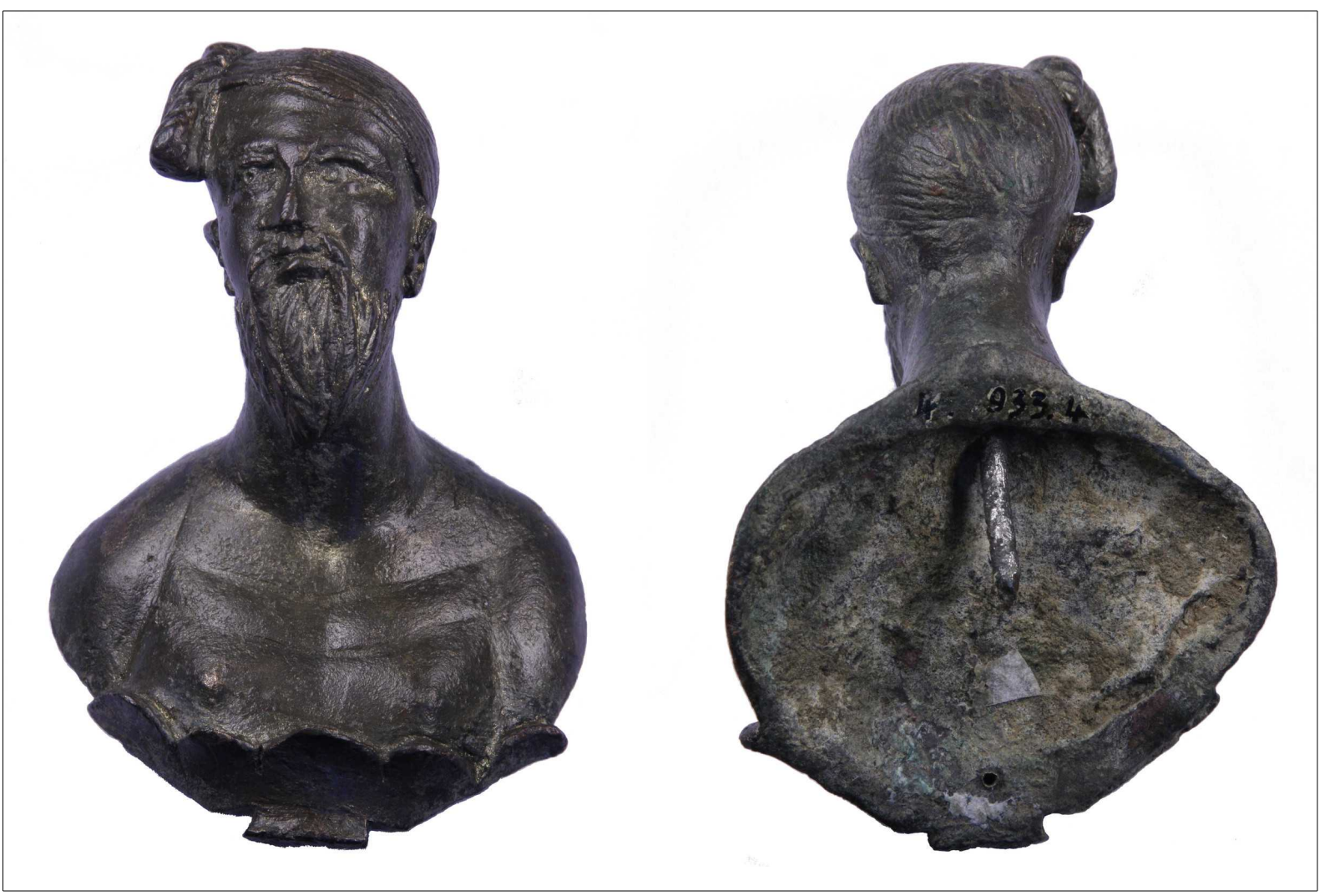

Fig. 5. The Suebian bronze bust from Brigetio in the Hungarian National Museum. (Photo: D. Bartus)

The closest parallel to the new bust from Brigetio can be found in Münich (Fig. 6). ${ }^{10}$ The 4,6 $\mathrm{cm}$ height of the piece is almost identical to the one found in the cellar. The two hair knots are also quite alike. The depiction of the pulled-up hair on the back side of the head is likewise very similar. There are triangle-shaped incisions starting from the left ear heading towards the right one and the nodus. The back side of the bust is hollow, unlike the one from the cellar. Nonetheless both were fastened the same way, that is, by a square-shaped iron pin, with only the empty hole visible now. Apart from these fine detailed similarities, we have to point out the differences too. The Münich calyx consists of only three leaves, two of which are placed under the shoulders in profile. The middle one is decorated with radial plastically shaped venations. The beard is short, unlike on the two Hungarian pieces. Its artistic craftsmanship is not as high as the one in the Hungarian National Museum, but is still superior to the new bust from Brigetio.

According to $\mathrm{H}$. Jucker the representation of a bust in leaf calyx originated in the funerary sculpture, and continued to be used as a depiction of the deceased. ${ }^{11}$ A. Kaufmann-Heinimann on the other hand saw them most often as furniture ornaments. ${ }^{12}$ The sepulchral view cannot be supported, since the new bust was found in the municipal part of Brigetio.

10 Archäologische Staatssammlung, KRIERER 2004, Kat. 289. Unfortunately, because the piece comes from the art market, nothing is known about about its find circustances.

11 JUCKER 1961, 137-138. This view was also taken over by K. R. Krierer. (KRIERER 2004, 119).

12 Kaufmann-Heinimann 1977, Nr. 173. They are primarily known from Gaul and Germania. See also Faider-Feytmans 1979, Nr. 152; JUCKER 1961, 163. 


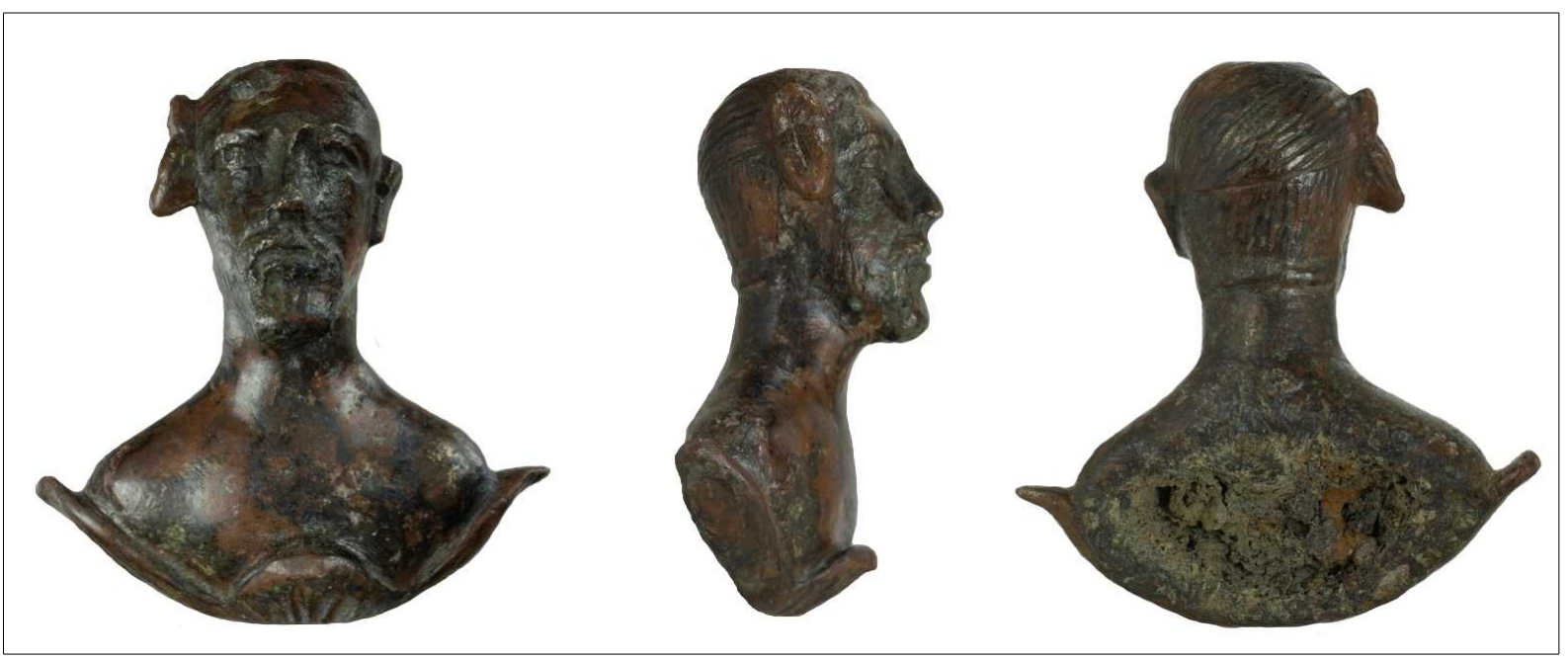

Fig. 6. Bronze bust of a Suebian man in Münich (Archäologische Staatssammlung, Photo: Manfred Eberlein).

When talking about busts with nodi, one must take into consideration the Mušov cauldron (Fig. 7) ${ }^{13}$ The vessel was found in a partially looted, but still very richly furnished grave of a Germanic chieftain. ${ }^{14}$ The four bronze busts $(8,7-9,4 \mathrm{~cm})$ depicting men with nodus were attached under the rim of a bronze cauldron. ${ }^{15}$ Behind the necks a bronze ring is placed, which serves as handle. Interestingly enough all four busts differ from each other in minor details. Still, up to our day these are the most elaborately crafted and of the highest quality, of all the busts with Suebian nodus, which are followed by the one in the Hungarian National Museum. The difference is most perceivable on the face and beard. However the nodus and the shoulders show great similarities. Horizontal incisions can also be seen on the Mušov busts, but these are shown more realistic and end before the shoulders.

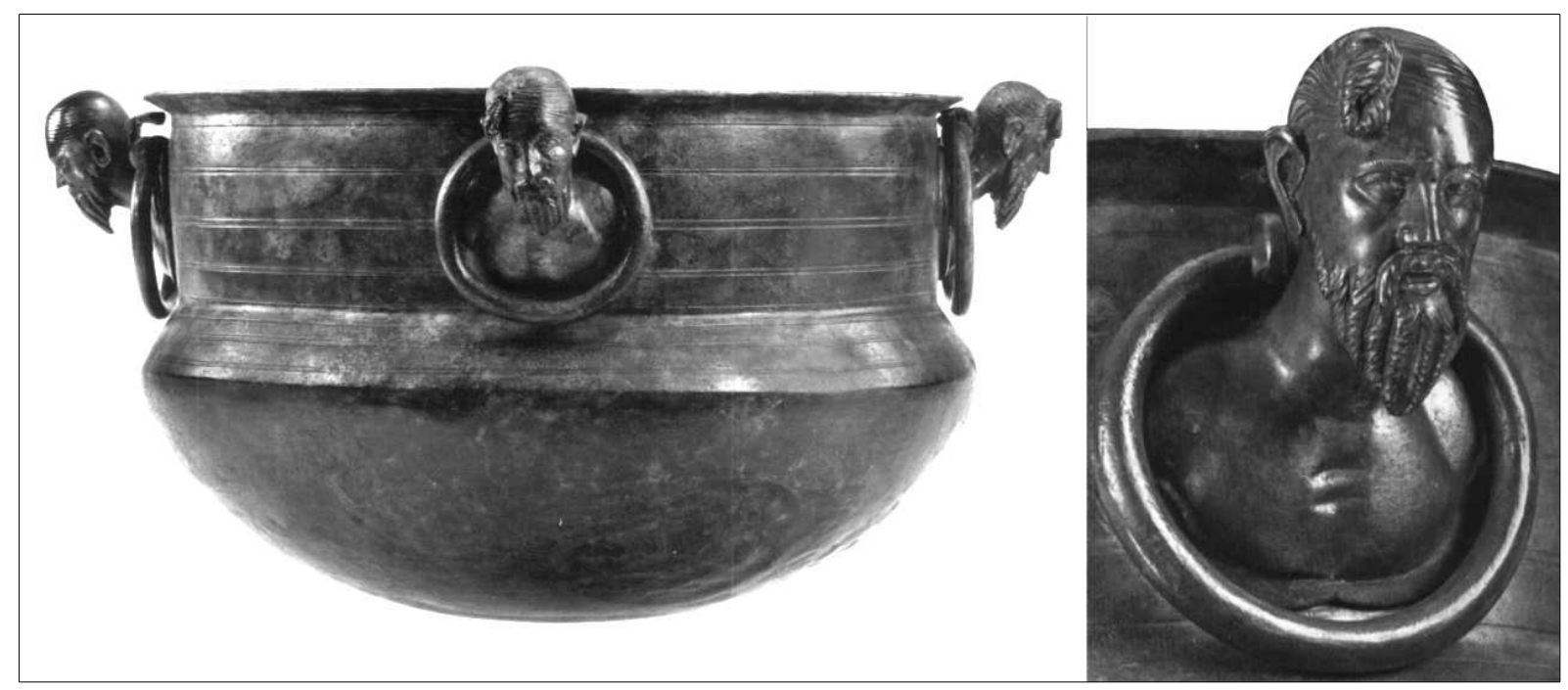

Fig. 7. The Mušov cauldron (After PešKA - TejRAL 2002, Taf. 88, Farbtaf. 6/4).

13 Krierer 2002, 374; KrIERER 2004, 113-118.

14 PEŠKA 2002, 3-9, 33-62. Then grave can be dated between the end of the Marcomannic wars and the beginning of the 3rd century. (PEŠKA - TEJRAL 2002, 505-508).

15 KÜNZL - KüNZL 2002, 569. F 2. 


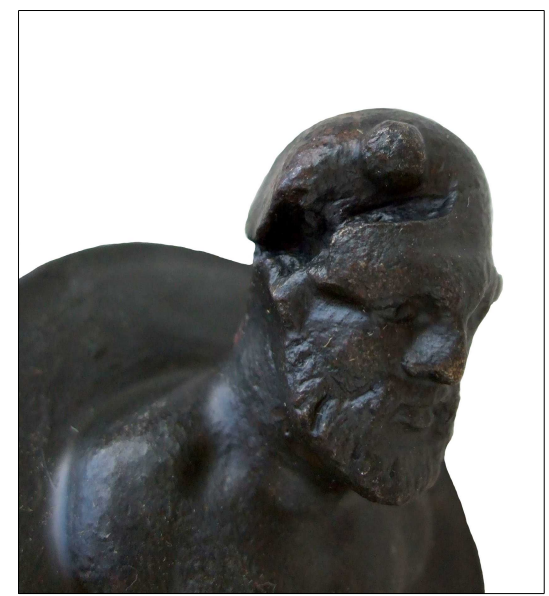

Fig. 8. Bust of a Suebian man in the LVR-Landesmuseum Bonn

(Photo: J. Komp, LVR-Landesmuseum Bonn).

Listing the male bronze busts with nodus, one must also add the one in the Rheinisches Landesmuseum Bonn, which until now has been neglected by the scholars. ${ }^{16}$ Unfortunately it also lacks any information about its find spot or circumstances. This piece differs in many ways from the previous ones (Fig. 8-9). Peculiar is that the bust does not stand alone, but was cast together with a bigger bronze object. The $6,5 \mathrm{~cm}$ tall bust is located in the middle of a round disk, the other side of which is equipped with a vertical slab widening towards its end, where it takes a $90^{\circ}$ turn. One side is flat, while there is a spike protruding from the other, where the two edges of the slab also bend towards. The bust itself also differs quite a bit from the other ones. The head is disproportionally large compared to the chest. The nodus is not above the temple, but slightly dislocated above the right eye. The short beard is not pointed or triangular shaped, it resembles the Münich piece, but is more pronounced. The chest is depicted with almost the same realism as the Mušov ones. Abrasion marks can also be seen on the Bonn piece, especially on the top of the head. Furthermore on the right temple and ear a cross-shaped injury can be seen that runs to the nodus. The function of the piece could not yet be convincingly determined. H. Menzel interpreted it as a wooden furniture piece, most likely as an armrest decoration. ${ }^{17}$ The very complicated construction of the find makes this improbable, since there a much simpler piece would suffice, which would also be easier to produce.

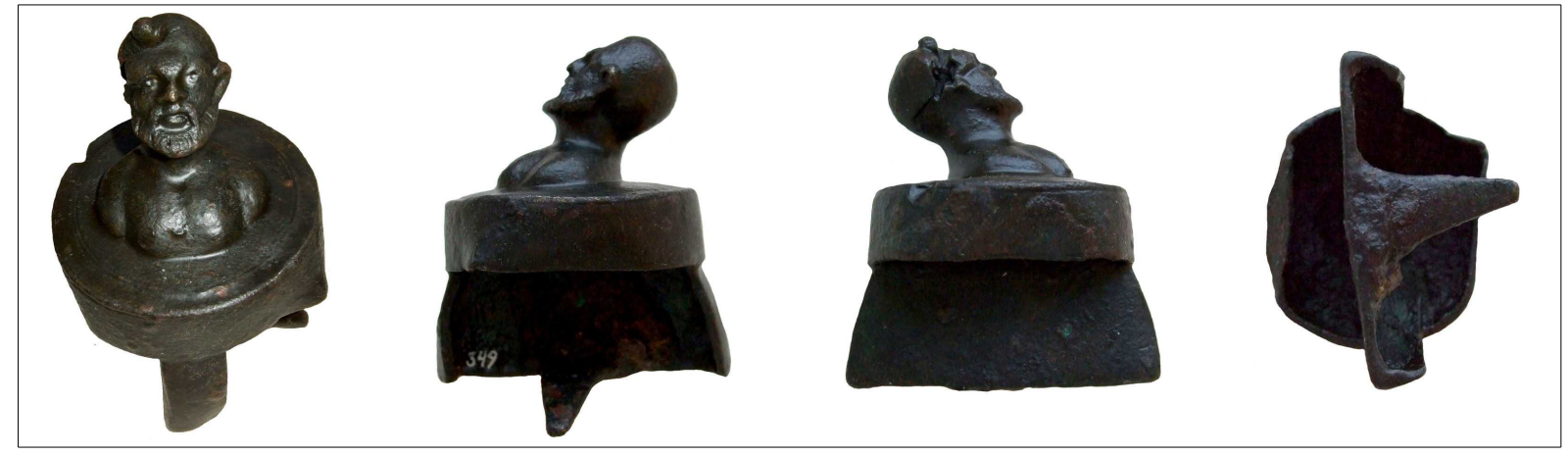

Fig. 9. Bust of a Suebian man in the LVR-Landesmuseum Bonn (Photo: J. Komp, LVR-Landesmuseum Bonn).

From Eisenstadt came a 3,8 cm tall head with some minor parts of the chest and shoulders, ending in an iron pin (Fig. 10.1). ${ }^{18}$ Similar is a head from Mannersdorf (4 cm) (Fig. 10.2) and one in the Museum Carnuntinum (Fig. 10.3) that also shows a small part of the shoulders. ${ }^{19}$ It is interesting to note that these three busts, looking very much alike came from the same region, that is, around Carnuntum. Therefore it would not be unreasonable to suggest they

16 Rheinisches Landesmuseum Bonn, Inv. Nr. 349; Menzel 1986, Nr. 488. Although it was published by H. Menzel, he failed to mention the bust with the nodus, and the picture in his catalogue did not portray the piece from the front.

17 MenZel 1986, Nr. 488.

18 NOWAK 1997, 72. Abb. 126; KrIERER 2004, Kat. 297.

19 Schumacher 1935, Nr. 110; Fleischer 1967, Nr. 204; Ubl 1976, 267-268; Krierer 2004, Kat. 280, 285. R. Fleischer supposes that the piece in the Museum Carnuntinum was found in Carnuntum. 
could have come from the same workshop. Although it cannot be attested with certainty that it was in Carnuntum, since the bust kept there is without a proper findspot. There is also an 11,2 cm tall terracotta bust, now in Bonn, that emerged in the Roman art market. ${ }^{20}$

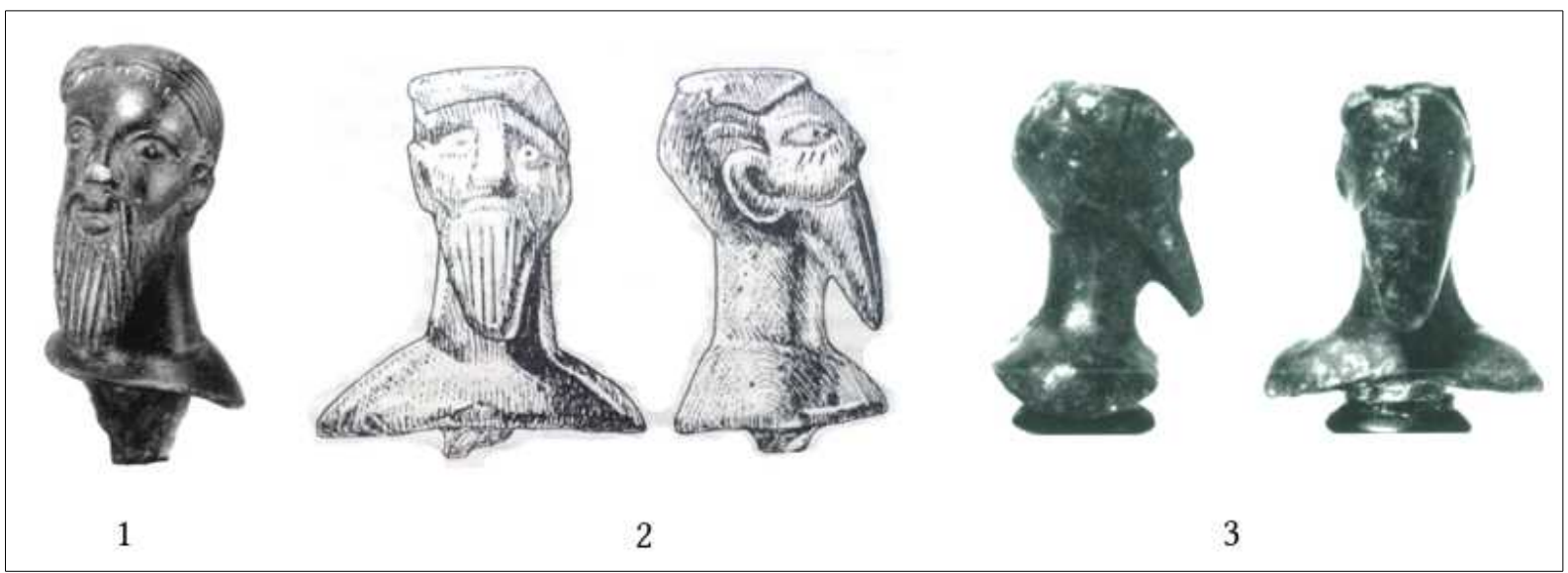

Fig. 10. 1. Bust of a Suebian from Eisenstadt (After KrIERER 2002, Tafel 22/1).2. Bust of a Suebian from Mannersdorf (After Ubl 1976, 263). 3. Bust of a Suebian in the Museum Carnuntinum (After FleIscher 1967, Tafel 108/204).

\section{Heads}

As for the heads there are 11 pieces in bronze and terracotta. From Brigetio itself, in addition to the newly discovered one, two more bronze heads are known. In 1963 a small head (4,5 $\mathrm{cm}$ tall 2,5 $\mathrm{cm}$ wide and 1,5 cm deep) was given to the Hungarian National Museum (Fig. 11). ${ }^{21}$ It has a cone-shaped neck that rests on a ring and a cone-shaped cylindrical base. The long head has a full and pointy beard, almond-shaped eyes, small round mouth and combed hair that is tied up in a knot at the right temple. The hair, beard, eyes and mouth are incised.

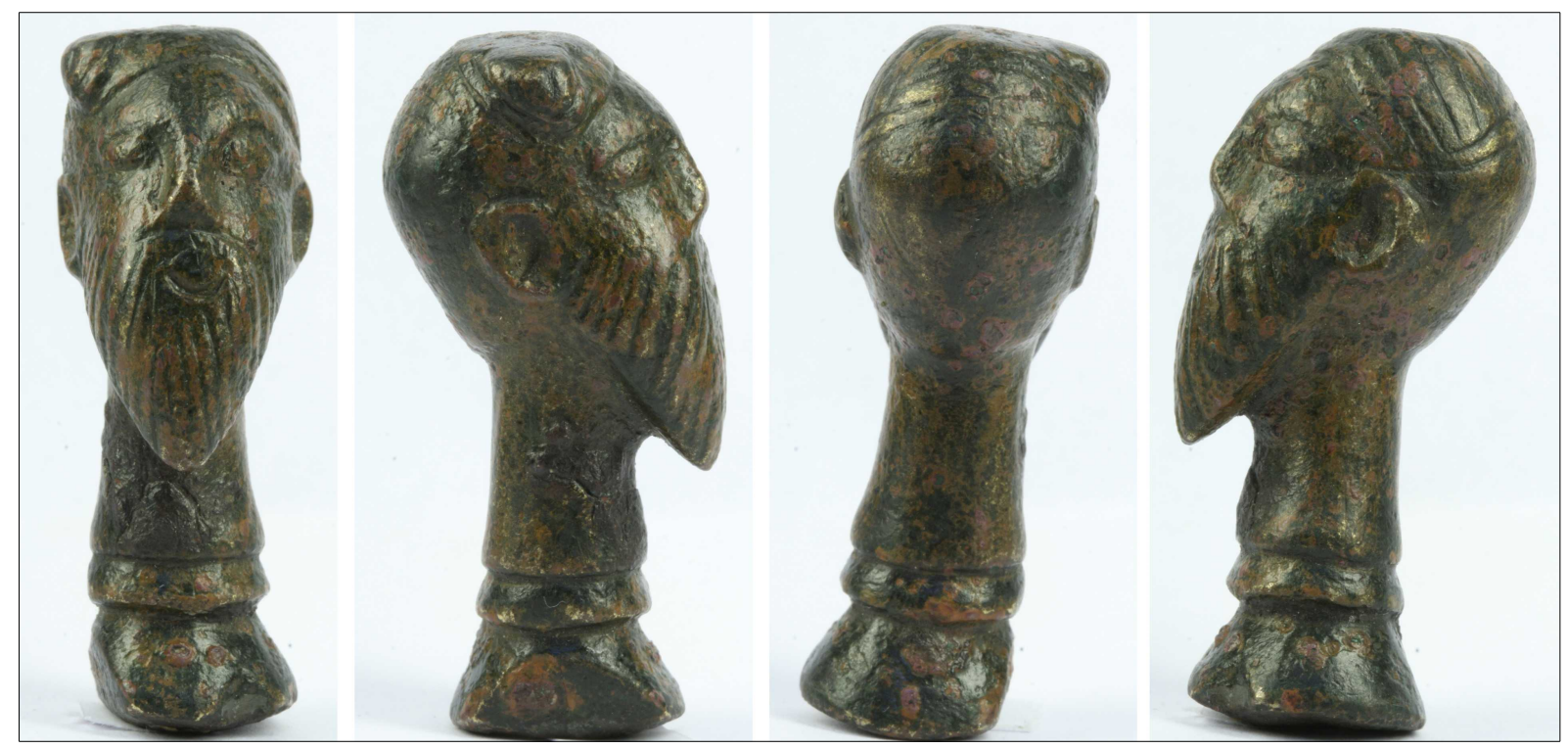

Fig. 11. Head of a Suebian in the Hungarian National Museum (Photo: D. Bartus).

20 Schumacher 1935, Nr. 87; Krierer 2004, Kat. 303.

21 I am greatly indebted to Dávid Bartus for bringing this piece to my attention and also kindly providing me with his pictures. Hungarian National Museum Inv. Nr. 63.27.3. 


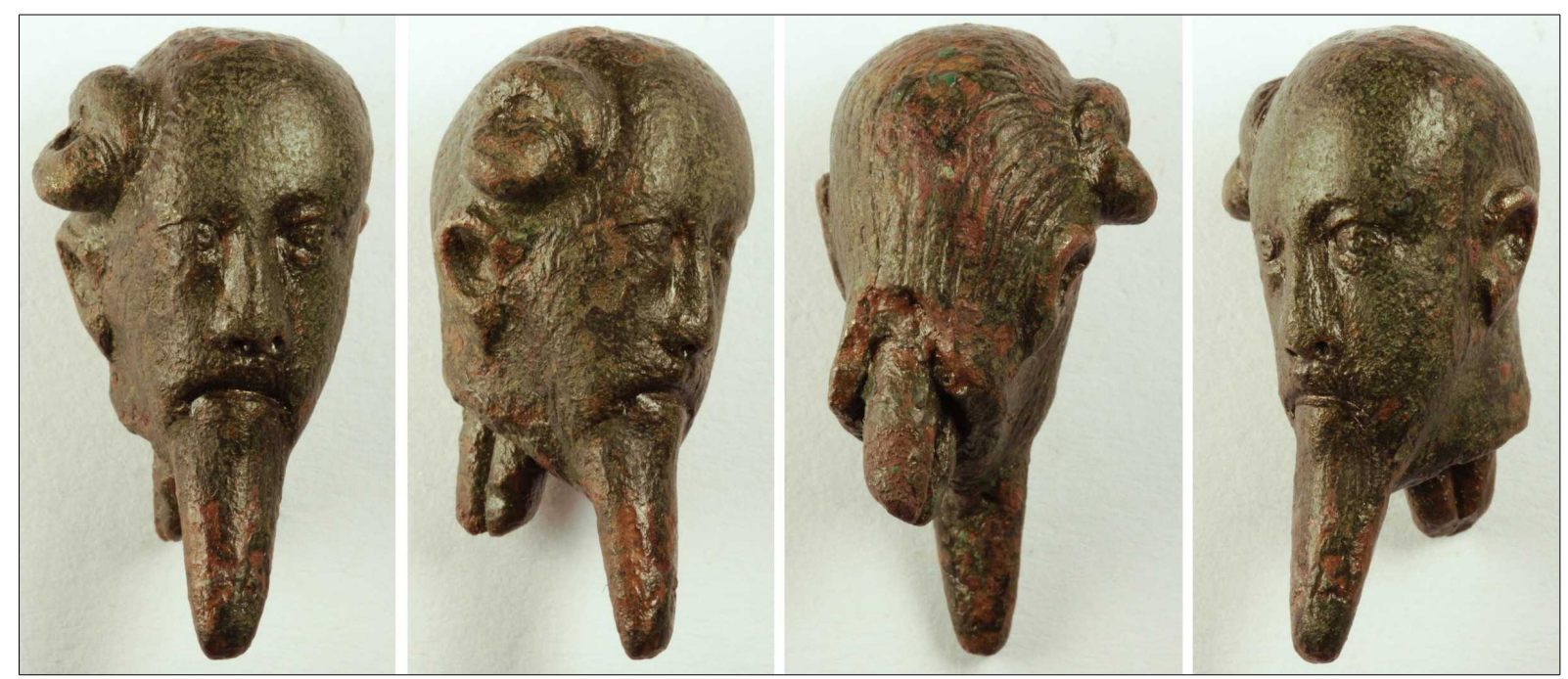

Fig. 12. Bronze head of a Suebian from Brigetio (Photo: D. Bartus).

The second head, measuring 4,1 ×2,2 × 1,8 cm, was found in 1990 in the canabae of Brigetio, west of the legionary fortress, south of the via principalis line (Fig. 12). ${ }^{22}$ It has a long and narrow beard, which is also true of the whole head. Its neck ends abruptly where it was originally attached to some presumably wooden surface. This is of particular interest regarding the newly excavated Germanic head.

From Brigetio (Szőny-Kurucdomb) comes also a terracotta form in the shape of a head with a nodus. It was most probably used to make wax models for the bronze casting (Fig. 13.1). ${ }^{23}$ Its height and with of $4 \times 3,6 \mathrm{~cm}$ fits in nicely with the rest of the small bronze heads.

A small $(4,2 \mathrm{~cm})$ bronze head is known from Dunapentele, Roman Intercisa, with long and narrow neck, beard and nodus (Fig. 13.2). ${ }^{24}$ This piece stands the closest to the head in the Hungarian National Museum, because it also has a cone-shaped neck with a ring on it, but the craftsmanship and decoration is also similar.

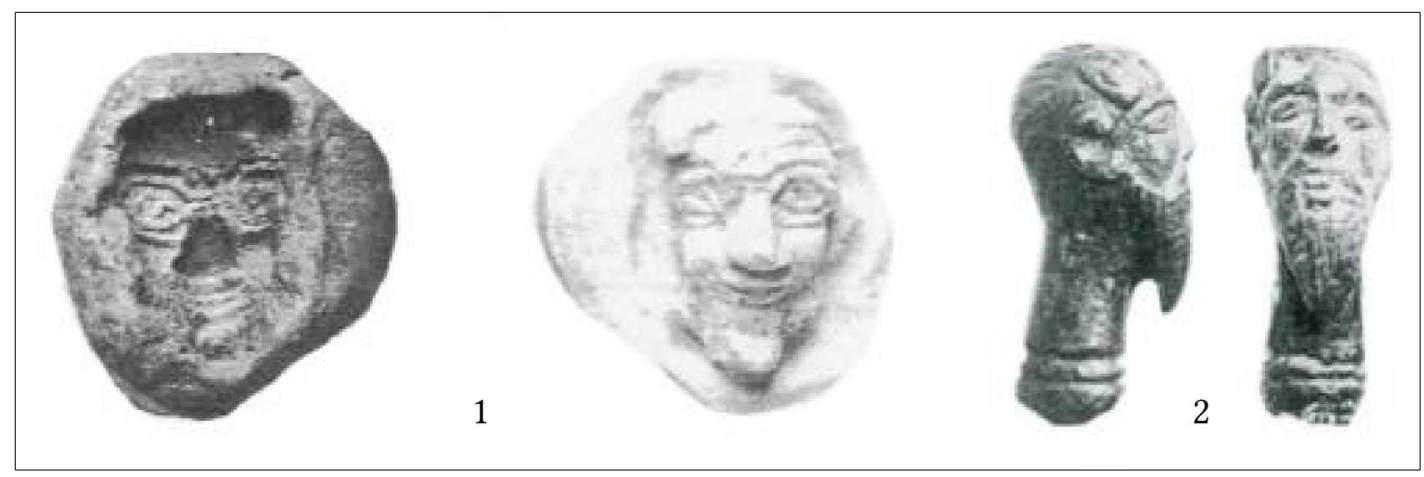

Fig. 13. 1.Terracotta mould of a Suebian head from Brigetio (KRIERER 2004, Tafel 31/1). 2. Bronze head of a Suebian from Dunapentele (KrIERER 2004, p. 144. Abb. 142).

22 Kuny Domokos Museum, Inv. Nr. 92.108.1. PeténYi 1993, 57.

23 Járdányi-Paulovics 1945, 244; Krierer 2004, Kat. 308. Bónis 1977, 132.

24 Schumacher 1935, Nr. 111; JÁrdÁnyi-Paulovics 1945, 252; Krierer 2004, Kat. 281. 


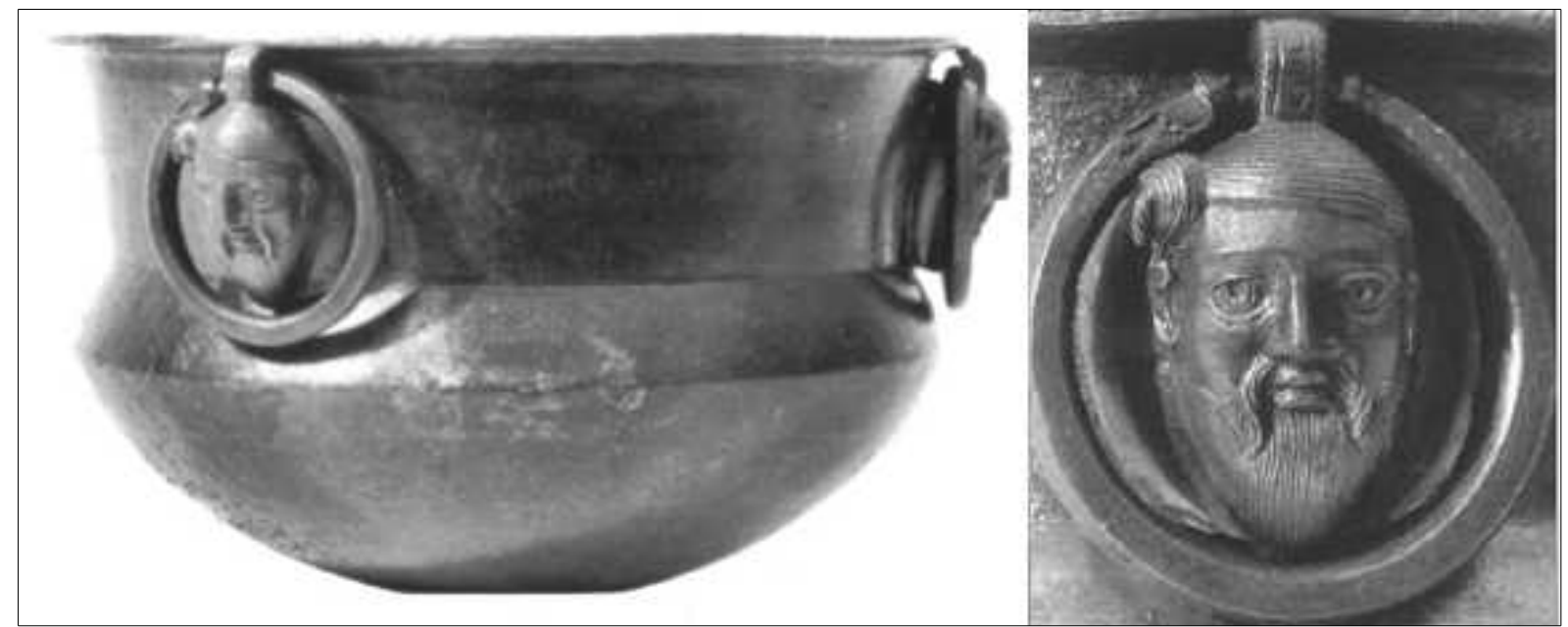

Fig. 14. The Czarnówko cauldron (after PešKa - TeJRAL 2002, Taf. 32/1).

Bronze heads with nodus were also found in the grave of a Germanic chieftain in Czarnówko, northern Poland (Fig. 14). ${ }^{25}$ The four heads are decorating a cauldron, like the one from Mušov. ${ }^{26}$ The heads also differ in minor details, and were also attached under the rim, but here the rings are found above, and not behind the heads. Big dissimilarities can be found between the portraits of the Mušov and Czarnówko pieces. The eyes are not narrow and almond shaped, but big and round. The approximately $5,5 \mathrm{~cm}$ tall heads are elongated, but the faces are much fuller. ${ }^{27}$ The nodi are tight and spherical knots, and have only a small hanging part. The findspot close to the Baltic Sea is unusual, but then again the two bog bodies with the nodus are also found in northernmost Germany, in Schleswig-Holstein.

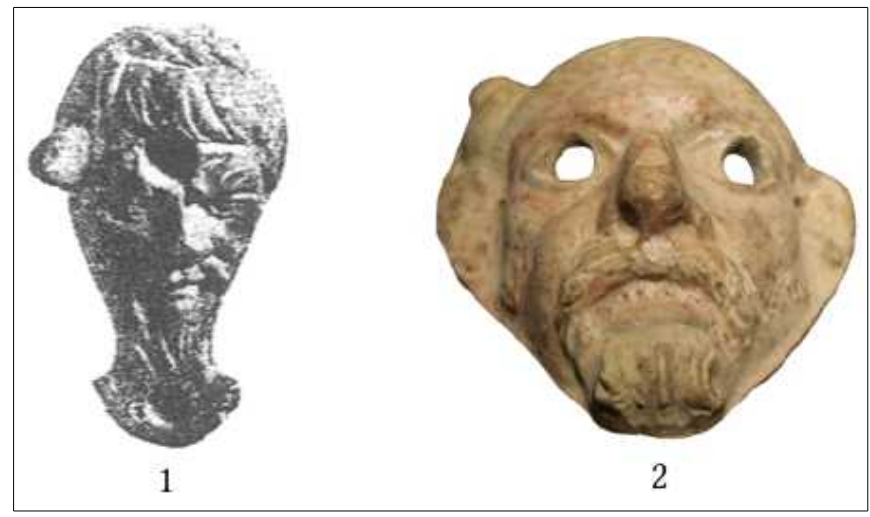

Fig. 15. 1. A lamp in shape of a Suebian head from Osijek (KRIERER 2004, Taf. 21/4).

2. A terracotta maks in the British Museum

(http://en.wikipedia.org/wiki/Suebian_knot\#mediaviewer/File:Terracotta_Germanic_at_British_Museum.jpg).

Apart from the bronze heads, there are terracotta ones too. A terracotta lamp is known from Osijek in form of a Suebian man's head with nodus (Fig. 15.1). ${ }^{28}$ A mask from the British Museum also shows the typical Suebian headdress, but in contrary to the other representations it does not portray a long and narrow head (Fig. 15.2). ${ }^{29}$

25 The grave can be dated to the second part of the 2nd century and the first decades of the 3rd century. (MĄczyŃsKARUDNICKA 2004, 397-400, 418; KRIERER 2002, 384-385; KRIERER 2004, 127-128).

26 The territory of Mušov as well as Czarnówko never formed part of the Roman Empire.

27 MĄCZYŃSKA-RUDNICKA 2004, 400/1.

28 Schumacher 1935, Nr. 94; JÁrdányi-Paulovics 1945, 241; Krierer 2004, Kat. 48.

29 18,5 cm tall. SCHumacher 1935, Nr. 88; KrIERER 2004, Kat. 305. 


\section{Standingfigures}

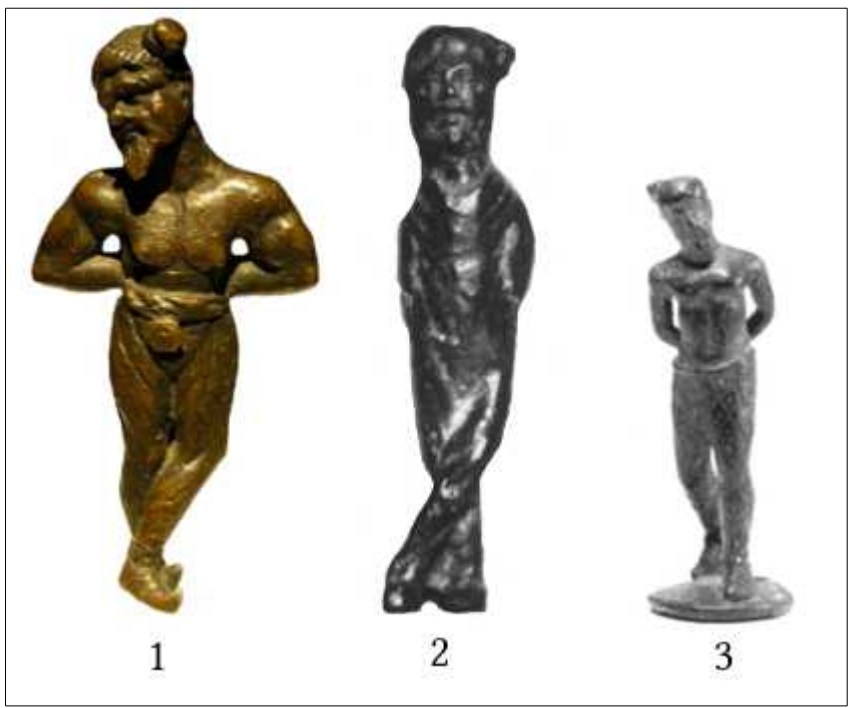

Fig. 16. 1. Application in form of a Suebian from Vienna (http://en.wikipedia.org/wiki/Suebian_knot\#mediaviewer/ File:Vindobona_Hoher_Markt-79.JPG). 2. Gilded bronze figure of a Suebian from Vienne (Schumacher 1935, Taf. 36/138). 3. Bronze statuette of a Suebian in the British Museum (KrIERER 2002, Tafel 23/2).

\section{Seated figures}

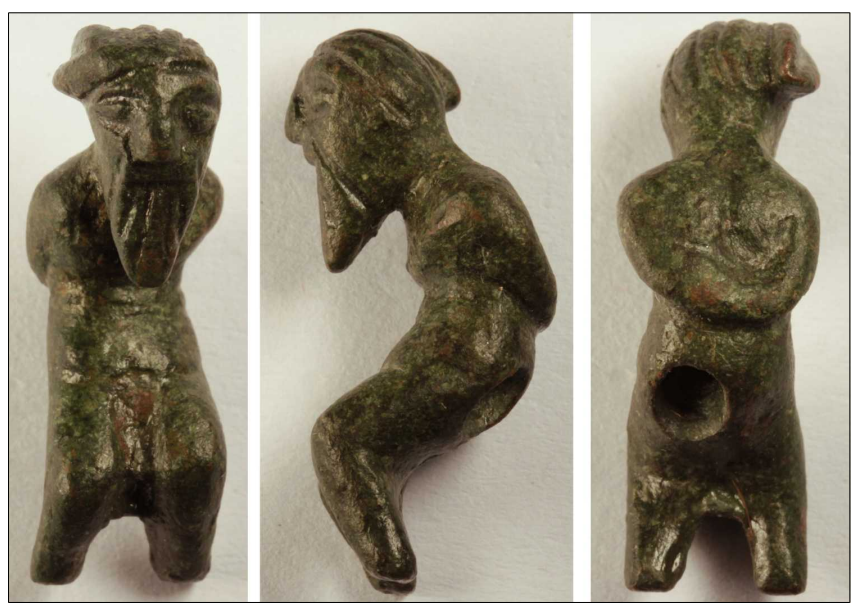

Fig. 17. Seated bronze statuette of a Suebian from Brigetio (Photo: D. Bartus).
Full-bodied depictions with nodus are also known, but only in bronze, and they are considerably fewer than the heads and busts. There are only three pieces showing standing germani with nodus, who are always portrayed as captives, with hands bound behind their back. An $11 \mathrm{~cm}$ high application is known from $\mathrm{Vi}$ enna with crossed legs, and the nodus is on the left side of the head (Fig. 16.1). ${ }^{30}$ The same can be seen on another $10,8 \mathrm{~cm}$ tall gilded application from Vienne that has the nodus on the left side of the head (Fig. 16.2) ${ }^{31}$ The British Museum keeps a similar $7 \mathrm{~cm}$ tall bronze statuette, with the figure stepping forward instead of crossed legs (Fig. 16.3). ${ }^{32}$

There are also three seated bronze figures with nodus and hands bound behind their backs. One was found in the canabae of Brigetio, west of the military camp, south of the via principalis line. The statuette measures $3,5 \times 1 \mathrm{~cm}$, with a $0,5 \mathrm{~cm}$ wide and $0,4 \mathrm{~cm}$ deep round hole at the rear, where it was fastened to some other material (Fig. 17). ${ }^{33}$ Another $5 \mathrm{~cm}$ tall seated German figure with nodus is kept in the Kestnermuseum in Hannover (Fig. 18.1). ${ }^{34}$ Interestingly enough it has a large ring around its right leg, the function of which is yet to be resolved. Similar in size

(5,5 cm tall) is statuette found in Romania with the nodus on the left side of his head (Fig. 18.2). ${ }^{35}$ It is seated on a base with which it was cast together in one piece.

30 Bieńkowski 1928, 50-51; Schumacher 1935, Nr. 137; Járdányi-Paulovics 1945, 247-248; Fleischer 1967, Nr. 200; KreILINGER 1996, Kat. 168; KrIERER 2004, Kat. 274.

31 Schumacher 1935, Nr. 138; Kreilinger 1996, Kat. 169; Krierer 2004, Kat. 257.

32 Schumacher 1935, Nr. 100; Krierer 2004, Kat. 272.

33 Inv. Nr. 92.107.1. S. Petényi supposes that a cavity line below the chest reflects that the upper body was also tied up. PETÉNyi 1993, 57.

34 BieńKowski 1928, 53-54; Schumacher 1935, Nr. 103; Krierer 2004, Kat. 242. K. Schumacher notes that the statuette could come from Italy.

35 SChumacher 1935, Nr. 104; KrIERER 2004, Kat. 291. 


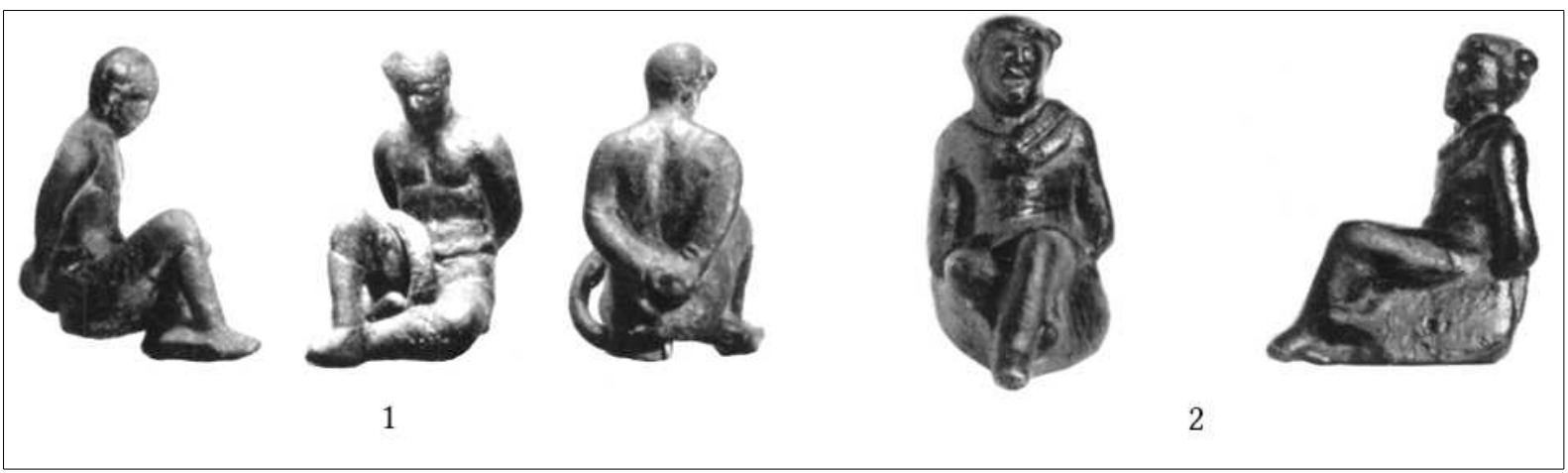

Fig. 18. 1. Seated bronze statuette of a Suebian in Hannover (Schumacher 1935, Tafel 31/103).

2. Seated bronze statuette of a Suebian from Romania (Schumacher 1935, Tafel 31/104).

\section{Kneeling figures}

There are only two statuettes of kneeling Germans with nodus known to us today. ${ }^{36}$ Both of them are down on one knee, and extending their hands in an act of supplication. A $12 \mathrm{~cm}$ tall beardless figure is kept in the Cabinet des Médailles in Paris (Fig. 19.1). ${ }^{37}$ Another $7 \mathrm{~cm}$ tall kneeling German with the nodus on the left side of his head is now in the Kunsthis torisches Museum, Vienna (Fig. 19.2). ${ }^{38}$

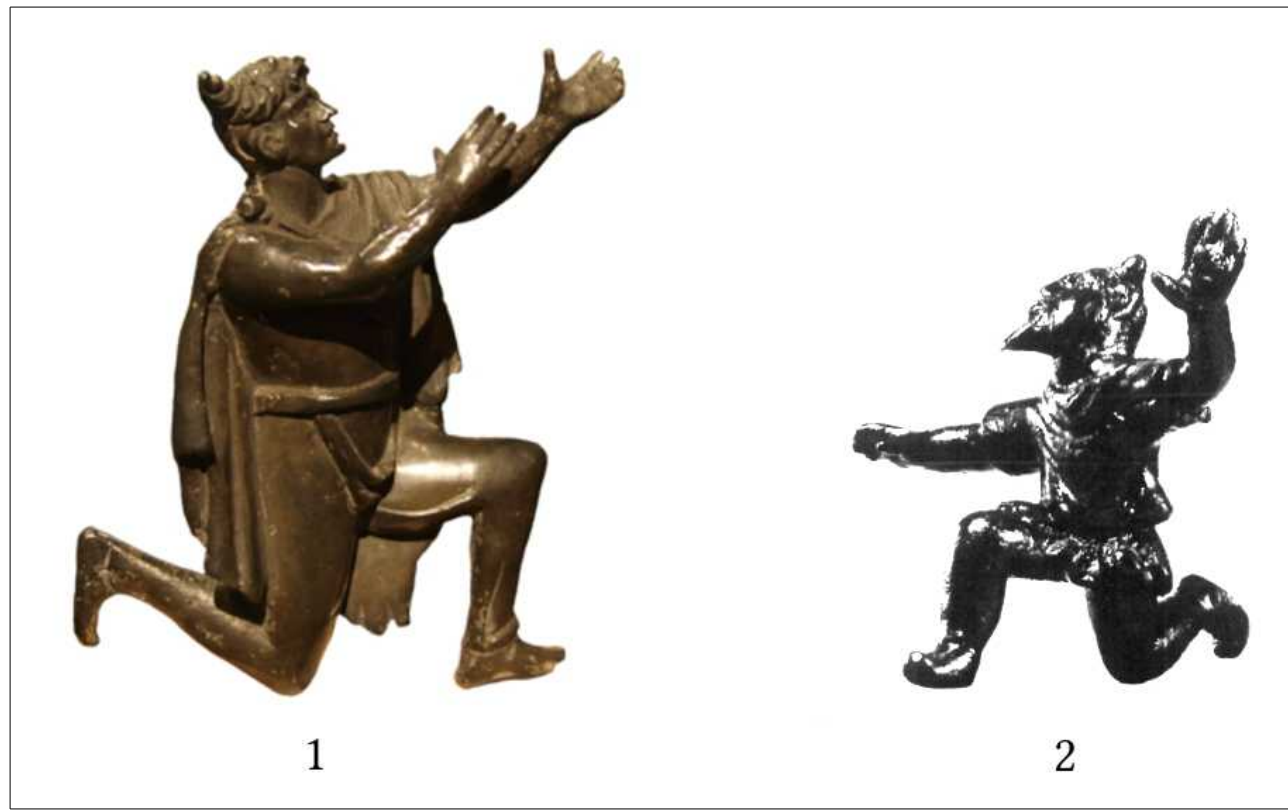

Fig. 19. 1. Kneeling Suebian figure in Paris

(http://de.wikipedia.org/wiki/Suebenknoten\#mediaviewer/File:Bronze_figure_of_a_Germanic_Biblioth\%C3\%A8que_Nationale.jpg).

2. Kneeling Suebian figure in Vienna (GschwantLer 1986, Abb. 339).

36 While doing research for this article I came across a very interesting picture on Wikipedia. It shows a silver statuette of a kneeling man with nodus, wrinkled trousers, without beard and hands bound behind his back (http://en.wikipedia.org /wiki/Suebian_knot\#mediaviewer/File:IArta_romana_prizonier_MG_1761_02.JPG). The only information that could be gathered was that it was exhibited in the Aurul și argintul antic al României temporary exhibition from 19th December to 23rd April 2014 in the National Museum of Romanian History (http://www.mnir.ro/index.php/aurul-si-argintul-antic-alromaniei-2/). This high quality piece would be the only silver depiction with nodus, so a publication is highly anticipated.

37 BieńKowski 1928, 57-58; SCHUMACher 1935, 142; Kreilinger 1996, Kat. 163; Krierer 2004, Kat. 262.

38 Gschwantler 1986, Kat. 315; Krierer 2004, Kat. 295. (K. R. Krierer suggested that it was probably found in Carnuntum or Brigetio). 


\section{Recumbent figures}

There is only one recumbent application with nodus found in Apt, France. ${ }^{39}$ It is a $12,5 \mathrm{~cm}$ long piece depicting a fallen Germanic, at the right hip there is a small hole for the fitting (Fig. 20). In his right hand he is holding some kind of a weapon, which is now lost for the most part.

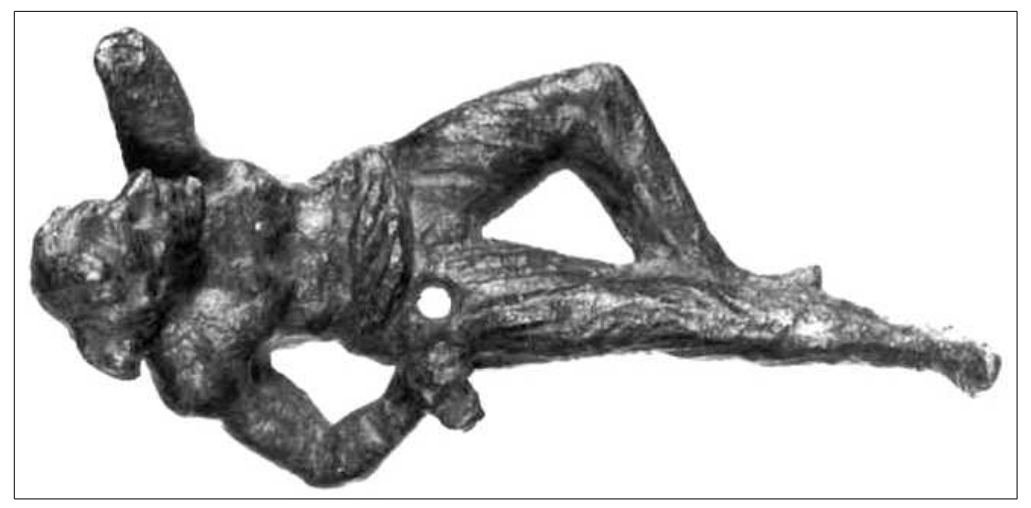

Fig. 20. Recumbent Suebian from Apt (KRIERER 2002, Tafel 22/1).

From these representations it can be concluded that the Seubi were in most cases represented with a long, narrow head and beard, with wrinkled trousers, bare chest and of course the nodus. The artistic quality and craftsmanship of the finds show a great variety from outstanding to simple and unsophisticated ones. This also makes it likely that the Romans themselves did not regard the Germans from one perspective, but had a more detailed view. Apart from symbolising the enemy they could have been used to express foreignness, in contrast to the non-Roman world that could have possessed some special charm.

\section{Dating}

The significance of these newly discovered bronze finds from Brigetio lies in, apart from the Mušov and Czarnówko cauldrons, that these are the only busts and heads with nodus discovered at a properly documented modern excavation. ${ }^{40}$ This fact is especially important for their dating, which can also serve as a valuable chronological pinpoint for the other similar Germanic representations. The rest of the bronze and terracotta finds with nodus are at museums usually without a precise findspot, or if it is known, they are normally just stray finds. Without solid chronological data, only stylistic methods and historic events can be used for dating, neither of them being very accurate.

The new bust was found in a cellar in Brigetio, which can be dated to the transition of the Antonine and Severan Age, based on the finds unearthed from it. ${ }^{41}$ The reasonable conclusion is that the bust is connected to the Marcomannic wars ${ }^{42}$, which is very plausible considering the bust's theme and findspot. ${ }^{43}$ This is also the historic event that is usually seen as the trigger for the rest of the depictions with Suebian nodus. This truly seems most likely,

39 Bieńkowski 1928, 31-32; Schumacher 1935, Nr. 132; Kreilinger 1996, Kat. 91; Krierer 2004, Kat. 250.

40 The Mušov and Czarnówko cauldrons were discovered in the graves of Germanic chieftains, but there the long usage of the other buried finds poses a problem. This is further enhanced by the fact that these were Roman objects in barbarian context, so their prestige and exotic value must also be reckoned with.

41 The analysis of the terra sigillata finds from the cellar was undertaken by Zs. Szórádi in her BA thesis. SzóRÁdI 2010, 25-27.

42 According to I. Járdányi-Paulovics the depiction of Germans became a trend in this era in Pannonia. (JÁRDÁNYI-PAULOVICS $1945,249-250,258)$. It still remains an open question if these were produced during the war or after the peace treaty. K. R. Krierer puts the production the date of these busts after the end of the war. (KRIERER 2004, 83-84, 119, 124-125).

43 This dating was anticipated for similar pieces. JÁrdánYi-Paulovics 1945, 258; PetÉnYi 1993, 58; KRIERER 2004, 124. 
but in some cases an earlier or later date cannot be excluded. The head found in 2014 in Brigetio, although it came from a documented excavation, cannot be dated securely. This is because it came from the top layers, which were still contaminated with modern finds. We can only learn that it was last used in the civil town of Brigetio.

\section{Distribution}

The 32 bronze and terracotta depictions with Suebian nodus were found all over the European continent. Of the pieces with findspot eight came from the Barbaricum, two from Gaul, one from Italy, one from Dacia. The biggest part however, 14 pieces, came from the Roman province of Pannonia, especially from sites along the Danube. ${ }^{44}$ The two new finds from Brigetio affirm the leading role of the city amongst the Suebian representations. ${ }^{45}$ Since there are considerable traces that prove the existence of bronze workshops, it is not unreasonable to suppose local production. ${ }^{46}$ In addition to the previously discovered finds, the new ones prove that the Suebian representations were not restricted to the military sphere (legionary fortress and canabae), but were also present in the municipium. So these were known and employed by the whole population. This is not surprising since the Suebi lived just across the Danube, so they were in everyday contact, both friendly and hostile. Further more the two cauldrons decorated with Suebian busts were found on barbarian territory.

\section{Function}

A very difficult and important question is what the purpose of these figures with Suebian nodus was. The answer is problematic due to the lack of find circumstances and that they are usually not intact, but some parts are broken away and missing. It can be assumed though that they all mostly served decorative purposes. Only the function of the Osijek lamp, the Mušov busts and the Czarnówko heads is known, the latter ones as attaches for the cauldron's handles. ${ }^{47}$ This means that these Suebian figures adorned objects of everyday life, but some also served funerary purposes. The function of the rest of the finds remains an open question, but we have to bear in mind that if reused, they could have adorned several different objects. Their variety in form, size and quality leads to the conclusion that these were used for various purposes. A number of them show signs of iron pins or nails that were used to fasten them to some other object, most likely some wooden material that has deteriorated by now. The Dunapentele piece was suggested to have served as a knife hilt. ${ }^{48}$ The representations themselves also give clues to their function. The full-bodied pieces always depict the Germans in a conquered, defeated manner or begging for mercy. On the other hand the heads and busts are in some cases of poor artistic quality, but some are quite excellent. It is possible that these represented in some cases the vanquished enemy, but they could also be used for a pure decorative purpose. ${ }^{49}$

44 KRIERER 2004, 143-144.

45 Also from Brigetio is the funerary stele of Aelius Septimius that portrays a Roman soldier and a kneeling defeated German with nodus. The piece was not a real tombstone, but only that of a cenotaph. It can be dated to the last decades of the 2nd century to the beginning of the 3rd century AD. Hungarian National Museum Inv. Nr. 10.1951.102; CIL III 10 969; JÁrdÁnyi-Paulovics 1945, 211-218; BArkóczi 1957, 92-94; Krierer 2004, Kat. 41; NAgy 2007, Nr. 122.

46 Petényi 1993, 58-61; Bartus et Al. 2014, 35-36; Bartus - Borhy - Delbó - SzÁmadó 2014, 439.

47 It is questionable if the mask in London served as an actual disguise, or just as decoration.

48 FLEISCHER 1967, Nr. 204.

49 Antoninus Pius' REX QVADIS DATVS coins portray the Quadian king as partner and not a defeated enemy; standing in front of the emperor and receiving a wreath or diadem from him. The small dot-like protrusion on the king's temple that can be seen on better coins in real life, and the handing over instead of crowning, suggests that the Quadian king was wearing a nodus. JuHÁsz 2012, 3-4. 


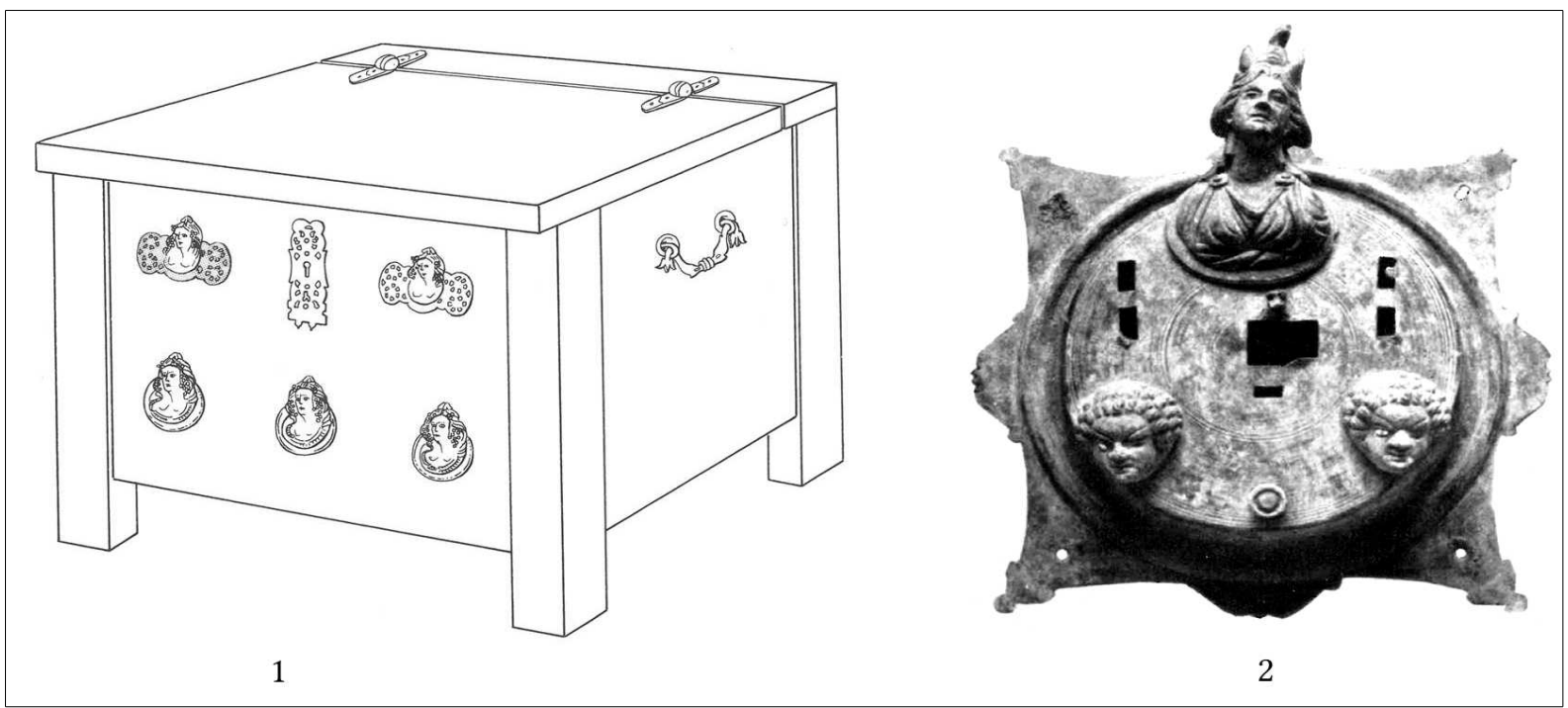

Fig. 21. 1. Reconstruction of the chest with busts from Eckartsbrunn (KeMKES 1991, Abb. 38). 2. Decorated chest lock from Lülleburgaz (MANSEL 1941, Abb. 15).

Due to some fortunate find circumstances the function of some decorative busts is known, which can be compared to the ones with nodus. ${ }^{50}$ High-quality ones were used used to adorn fulcra ${ }^{51}$, gates or doors. ${ }^{52}$ But more plausible is the comparison with big chests, two of which in Pompeii were fully preserved and decorated with fine busts of deities. ${ }^{53}$ Two elaborate ones were also found in the villa of Eckartsbrunn that were decorated with five Bacchus busts (9,7-11,55 cm) (Fig. 21.1). ${ }^{54}$ Their size and dating from the second half of the 2nd to the first half of the 3rd century dating coincides with the old Brigetio and Mušov pieces. A 2nd century Lüleburgaz tumulus also yielded a very interesting and elaborately formed chest. ${ }^{55}$ Above the keyhole the $12 \mathrm{~cm}$ high bust of the personification of Africa can be seen, under which two $4,5 \mathrm{~cm}$ tall negroid heads are placed (Fig. 21.2). ${ }^{56}$ The chest was decorated with four additional busts $(9,8-11,5 \mathrm{~cm})$, and three heads $(5,6-10 \mathrm{~cm})$. The bronze ornaments were probably placed, due to their height and large number, on a similarly proportioned chest as the previous ones. This in regard to the Germanic busts is of particular importance, since it proves that foreign ethnicities were depicted on chests. Another box from Lüleburgaz was decorated with two satyr heads $(3,5$ and $4,7 \mathrm{~cm})$, a Minerva $(3,7 \mathrm{~cm})$, and two gorgoneia $(3 \mathrm{~cm}) .{ }^{57}$ The $28 \times 23 \times 14 \mathrm{~cm}$, more modest dimensions of the box are easily compared to the smaller Suebian busts and heads.

50 Determining the function of the heads and the full-bodied representations is much more problematic, because of their greater number and the possibility of a much more versatile use.

51 The busts on fulcra usually came from the mythological and dionysiac sphere, and predate the Suebian ones, because these beds went out of use in the 1st century AD. However,the average size of these applications ranges between 6-13 $\mathrm{cm}$, which can be compared to the busts with nodus. BARR-SHARrar 1987, 1, 8, 84-86, 154-155, C 50-78, C 95-96, C 101-102, C 104, C 138, C 143; Mols 1999, 39.

52 A fine example from Ladenburg, dated between 125-150 AD was richly decorated with 16,5-18,5 cm tall busts, which exceed the Suebian ones. KünZL - KünZl 2003, 258-285, 314; KünZL - KünZL - Kaufmann-Heinimann 2003, 14-15.

$5392 \times 102 \times 58,5 \mathrm{~cm}$ Museo Archeologico Nazionale di Napoli, Inv. 73 021; 88,5×97×72 cm Inv. 73 022; PERNICE 1932, 86, 8889; De Caro 1994, Nr. 220; De LongPérier 1868, 171; MAU - Kelsey 1907, 255; Richter 1966, 114; Kaufmann-HeiniMANN 2003, 191, nr. 47.

54 Kemkes 1991, 305-312, 354-359, 365-366, 385-387. The wooden elements deteriorated, but with the help of the bronze parts M. Kemkes reconstructed two chests, which he interpreted as arca nummaria and vestiaria. The first belonged to the male, while the latter to the female sphere, so together they are regarded as the symbol of marriage. The chests, with the help of the Pompeian examples, were reconstructed as approximately the same size $(85 \times 100 \times 70 \mathrm{~cm})$.

55 MANSEL 1941, 150.

56 MANSEL 1941, 144-147.

57 MANSEl 1941, 131-132. 
Furthermore the chests and cellars did also have special a connection in the Roman times. The cellar as the storage place of chests is not surprising, since there they were already hidden from all unwanted attention, and they were difficult to access. In several cases chests were retrieved from cellars like in Pompeii, Eckartsbrunn and Augusta Raurica. ${ }^{58}$ From a cellar in the Vesuvian town a silver gilded chest came to light, which also contained numerous precious objects. In the cellar in Brigetio, a $6,95 \mathrm{~cm}$ wide handle came to light, where the Suebian bust was also found. The question remains unanswered, whether the bust and the handle are connected, or it is just a simple coincidence. ${ }^{59}$ If they did belong together, there is a reasonable possibility that they were originally part of a chest or a box.

\section{Summary}

In 2009 and 2014 during the excavations in Brigetio (Szőny-Vásártér) an interesting bronze bust and a head came to light, both showing the characteristic Suebian nodus. This special hairstyle is known from various other Roman artefacts from across Europe. The peculiarity of the new finds is that they come from a well-documented excavation. They fit well into a series of previously discovered similar pieces from Pannonia, where the greatest part of the bronze and terracotta finds with nodus come from. The two new artefacts furthermore confirm the leading role of Brigetio in the distribution of these peculiar finds, since more than half of all that was found in Pannonia came from this city. These depictions were popular amongst the Romans, especially on the Danube frontier around the time of the Marcomannic wars, to which period the newly found bust can also be linked. A more precise dating poses a problem, as does their function, but it is clear that they adorned various objects of everyday life, but also served funerary purposes.

\section{References}

Allison, P. M. 2006: The Insula of Menander at Pompeii Vol. 3: The finds, a contextual study. Oxford.

BArkóczi, L. 1957: Die Naristen zur Zeit der Markomannenkriege. Folia Archaeologica 9, 91-99.

BARR-Sharrar, B. 1987: The Hellenistic and Early Imperial decorative bust. Mainz am Rhein.

Bartus, D. - Borhy, L. - SzÁmadó, E. 2014: Short report on the excavations in the civil town of Brigetio (Szőny-Vásártér) in 2014. Dissertationes Arhaeologicae Ser. 3. No. 2 (2014) 431-436.

Bartus, D. - Borhy, L. - Delbó, G. - SzÁmadó, E. 2014: A new Roman bath in the canabae of Brigetio. Short report on the excavations at the site Szőny-Dunapart in 2014. Dissertationes Arhaeologicae Ser. 3. No. 2 (2014) 437-449.

Bartus, D. - Borhy, L. - Delbó, G. - Dévai, K. - Kis, Z. - Nagy, A. - Sey, N. - SzÁmadó, E. - Vida, I. 2014: Jelentés a Komárom-Szőny, Vásártéren 2012-ben folytatott régészeti feltárások eredményeiről - Bericht über die Ergebnisse der im Jahre 2012 in Brigetio (FO: Komárom/Szőny, Vásártér) geführten archäologischen Ausgrabungen. Kuny Domokos Múzeum Közleményei 20 (2014) 33-90.

BARTUs, D. 2011: Roman figural bronzes from Brigetio: preliminary notes. In: NovotnÁ, M. et al. (eds.): The phenomena of cultural borders and border cultures across the passage of time (From the Bronze Age to Late Antiquity). Anodos. Studies of the Ancient World 10. Trnava, 17-28.

58 Riha 2001, 110-112; Allison 2006, 314-317; Kemkes 1991, 304, 365. M. Kemkes also raised the question of wether the chests stood in the room on top of the cellar, but this could not be answered due to the insufficient preservation of the site.

59 The cellar was filled up with debris, so this problem can not be resolved. 
Bieńkowski, P. 1928: Les Celtes dans l'art mineur gréco-romains. Kraków.

BónIs, É. B. 1977: Das Töpferviertel am Kurucdomb von Brigetio. Folia Archaeologica 28, 105-142.

Borhy, L. - SzÁmadó, E. 2010: Komárom-Szőny, Vásártér. In: Kisfaludi, J. (ed.): Régészeti kutatások Magyarországon 2009. Budapest, 250-251.

DE CAro, St. 1994: Il Museo Archeologico Nazionale di Napoli. Napoli.

DE LONGPÉRIER, H. 1868: Recherches sur les insignes de la questure et sur les récipients monétaires. Revue Archéologique 18, 158-171.

FaIder-Feytmans, G. 1979: Les bronzes romains de Belgique. Mainz am Rhein.

FLeISCHER, R. 1967: Die römischen Bronzen aus Österreich. Mainz am Rhein.

Gschwantler, K. 1986: Guß und Form. Bronzen aus der Antikensammlung. Wien.

JÁRDÁNYI-PAULOVICS I. 1945: Germán alakok pannoniai emlékeken - Germanendarstellungen auf pannonischen Denkmälern. Budapest Régiségei 14, 205-281.

Jucker, H. 1961: Das Bildnis im Blätterkelch. Olten - Lausanne - Freiburg i. Br.

JuHÁsz, L. 2012: A REX DATVS érmek és előzményeik. Az Érem 2012/2, 2-6.

Kaufmann-Heinimann, A. 1977: Die römischen Bronzen der Schweiz I.Augst. Mainz am Rhein.

KemкEs, M. 1991: Bronzene Truhenbeschläge aus der römischen Villa von Eckartsbrunn, Gde. Eigeltingen, Lkr. Konstanz, Fundberichte aus Baden-Württemberg 16, 299-387.

KreILINGER, U. 1996: Römische Bronzeappliken. Historische Reliefs im Kleinformat. Heidelberg.

KrIERER, K. R. 2002: Germanenbüsten auf dem Kessel. Die Henkelattaschen des Bronzekessels. In: PešKA, J. - TejRAL, J. (eds.): Das germanische Königsgrab aus Mušov in Mähren. RGZM Monographien 55. Mainz am Rhein, 367-385.

Krierer, K. R. 2004: Antike Germanenbilder. Archäologische Forschungen 11. Wien.

KünZl, E. - KünZl, S. - Kaufmann-Heinimann, A. 2003: Katalog. In: KünZl, E. - KünZL, S. (eds.): Das römische Prunkportal von Ladenburg. Forschungen zur Vor- und Frühgeschichte in Baden Württemberg 94. Stuttgart 2003, 11-86.

KüNZL, E. - KÜNZL, S. 2002: Römische Metallgefäße. In: PešKA, J. - TEJRAL, J. (eds.): Das germanische Königsgrab aus Mušov in Mähren. RGZM Monographien 55. Mainz am Rhein, 569-580.

KüNZL, E. - KÜNZL, S. 2003: Türen der römischen Kaiserzeit. Rekonstruktion des Ladenburger Portals. Zusammenfassung. In: KüNZL, E. - KüNZL, S. (eds.), Das römische Prunkportal von Ladenburg. Forschungen zur Vor- und Frühgeschichte in Baden-Württemberg. Stuttgart, 249-314.

MĄczyŃsKa, M. - RudnickA, D. 2004: Ein Grab mit römischen Importen aus Czarnówko. Germania $82,397-429$

Mansel, A. M. 1941: Grabhügelforschung im östlichen Thrakien. Archäologischer Anzeiger, 119-187.

Mau, A. - Kelsey, F. W. 1907: Pompeii: Its life and art. London.

MenzeL, H. 1986: Die römischen Bronzen aus Deutschland III. Bonn. Mainz am Rhein.

Mols, S.T.A.M. 1999: Wooden furniture in Herculaneum. Amsterdam.

Nagy, M. 2007: Lapidarium. A Magyar Nemzeti Múzeum régészeti kiállításának vezetője: Római kőtár. Budapest. 
NowaK, H. 1997: Beschlag in Form einer Germanenbüste. In: Melchart, W. (ed.): Antike Kostbarkeiten aus österreichischem Privatbesitz. Wien, 72, Abb. 126.

Pernice, E. 1932: Hellenistische Tische, Zisternenmündungen, Beckenuntersätze, Altäre und Truhen. Die hellenistische Kunst in Pompeji 5. Berlin - Leipzig.

PešKa, J. - Tejral, J. 2002: Gesamtinterpretation des Königsgrabes von Mušov. In: PešKA, J. TejRal, J. (eds.): Das germanische Königsgrab aus Mušov in Mähren. RGZM Monographien 55. Mainz am Rhein, 501-513.

PešKA, J. 2002: Das Grab. In: PešKA, J. - TejRAL, J. (eds.): Das germanische Königsgrab aus Mušov in Mähren. RGZM Monographien 55. Mainz am Rhein, 3-71.

PetÉnyI, S. 1993: Neuere germanische Statuen aus Brigetio. Communicationes Archaeolgicae Hungariae, $57-62$.

Richter, G.M.A. 1966: The furniture of the Greeks, Etruscans and Romans. London.

Rina, E. 2001: Kästchen, Truhen, Tische - Möbelteile aus Augusta Raurica. Forschungen in Augst 31. Augst.

SCHUMACHER, K. 1935: Germanendarstellungen I. Mainz.

SzÓRÁDI, Zs. 2010: Terra Sigillata. Leletek a Brigetio-Vásártéren 2009-ben feltárt pincéből. Unpublished BA-thesis. Budapest.

UBL, H. 1976: Mannersdorf am Leithagebirge. Fundberichte aus Österreich 15, 267-268. 